of an $\alpha$-ketol ${ }^{9}$ (VI), derived from securinine, or application of the octant rule ${ }^{10)}$ predicts that an absolute configuration of norsecurinine at $\mathrm{C}_{9 b}$ should be $\mathrm{S}$-configuration.

Norsecurinine is, therefore, represented by either $\mathrm{Ia}$ or $\mathrm{Ib}$ and dihydronorsecurinine by either IIa or IIb. The stereochemistry at $\mathrm{C}_{9 a}$ will be discussed in a subsequent paper.

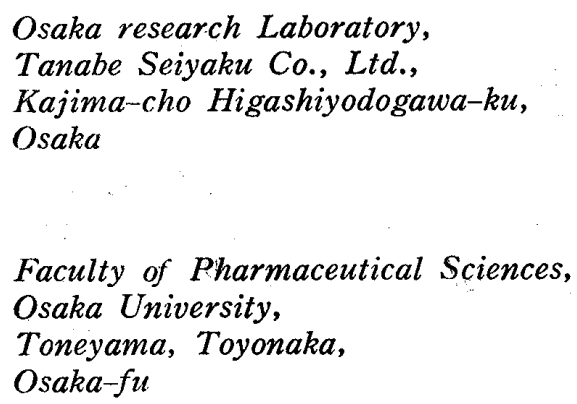

$\begin{array}{ll}\text { Seiichi Saito } & \text { (齐藤清一) } \\ \text { Tadasu Tanaka } & \text { (田中 雅) } \\ \text { Keishi Kotera } & \text { (小寺啓司) } \\ \text { Hideo Nakai } & \text { (仲井英雄) } \\ \text { Norio Sugimoto } & \text { (杉本典夫) } \\ \text { Zen-ichi Horii } & \text { (堀井善一) } \\ \text { Masazumi Ikeda } & \text { (池田正澄) } \\ \text { Yasumitsu Tamura } & \text { (田村恭光) }\end{array}$

Received September 14, 1964

9) Z. Horii, M. Ikeda, Y. Yamawaki, Y. Tamura, S. Saito, K. Kotera : Tetrahedron, 19, 2101 (1963).

10) W. Klyne: Ibid., 13, 29 (1961).

\title{
On the Structure of Pergularin
}

The isolation of sarcostin (I), metaplexigenin (II), benzoylramanone (II), deacylcynanchogenin $(\mathbb{N})$, utendin (V), pergularin (V), and two other aglycones from Metaplexis joponica MaKino has been reported previously. ${ }^{1 \sim 5)}$ In this communication, the experimental result leading the structure of pergularin (V) is described. Pergularin (V), m.p. $220 \sim 234^{\circ}, \mathrm{C}_{21} \mathrm{H}_{32} \mathrm{O}_{5} \cdot 1 / 2 \mathrm{H}_{2} \mathrm{O}$ (Anal. Calcd. : C, 67.55; H, 8.85. Found : C, 67.65; H, 9.32). $[\alpha]_{589}^{19}-33^{\circ}\left(\mathrm{c}=0.1, \mathrm{MeOH}\right.$, from ORD measurement). IR $\nu_{\max }^{\text {Nujiol }} \mathrm{cm}^{-1}: 3550,3450,1720,1690$. Although V showed two bands in the carbonyl region of the infrared spectrum, ${ }^{11}$ it gave only a monooxime (VI) which revealed no carbonyl absorption. Therefore, VI possesses only one carbonyl group. Very similar facts were reported in the case of deacylmetaplexigenin (IIa). ${ }^{2,3}$ Acetylation of $\mathrm{VI}$ with acetic anhydride-pyridine afforded a diacetate (VII), m.p. $130 \sim 137^{\circ}, \mathrm{C}_{25} \mathrm{H}_{36} \mathrm{O}_{7}$ (Anal. Calcd. : C, 66.94; H, 8.09. Found : C, 66.97; H, 8.46). The nuclear magnetic resonance spectrum of pergularin (V) showed three singlet at 8.96 $\left(18-\mathrm{CH}_{3}\right), 8.29\left(19-\mathrm{CH}_{3}\right), 7.43\left(17-\mathrm{COCH}_{3}\right) \tau$ in pyridine.* ${ }^{3}$ The optical rotatory dispersion curves of pergularin (VI), and its acetate (VII), in methanol showed negative Cotton effect.

*1 Pergularin (U) is practically insoluble to $\mathrm{CCl}_{4}$ and $\mathrm{CHCl}_{3}$.

*2 Pergularia japonica Thunв. is the synonym of Metaplexis japonica Makino.

*3 In this paper, 10 p.p.m. value (from tetramethylsilane, used as internal standard) is used as $\tau$.

1) H. Mitsuhashi, T. Nomura, Y. Shimizu, I. Takemori, E. Yamada: This Bulletin, 10, 811 (1962). In the report, pergularin was expressed as crystal 3 , and utendin as crystal 4 .

2) H. Mitsuhashi, T. Nomura : Ibid., 11, 1333 (1963).

3) Idem : Ibid., in press.

4) H. Mitsuhashi, T. Nomura, M. Hirano: Presented as a paper at the Annual Meeting of the Pharmacognostical Society of Japan, Sept. 19, 1964, Kanazawa.

5) H. Mitsuhashi, T. Nomura : Steroids, 3, 271 (1964). 
These curves were shifted about $10 \mathrm{~m} \mu$ to longer wave length in comparison with those of ramanone (IIa), and its acetate $(\mathbb{I l l} b),{ }^{2,5,6)}$ suggesting the presence of a $\alpha$-ketol system. ${ }^{0,7)}$

TABLE I.

\begin{tabular}{cccc}
\hline Compound & Trough $[\varnothing]_{311}$ & Peak $[\Phi]_{288}$ & $\mathrm{a} \times 10^{-2}$ \\
\hline VI & -3878 & +5086 & -89.6 \\
VII & -5037 & +4606 & -96.4 \\
\hline
\end{tabular}

After VI was treated with $3 \%$ methanolic potassium hydroxide for $24 \mathrm{hr}$. at room temperature, the resulting mixture showed only one spot which was identified as starting material (V) on paper partition chromatogram $\left(\mathrm{CHCl}_{3} /\right.$ formamide). ${ }^{8}$ ) This results indicated that pergularin (V) could not be isomerized under this condition, which led

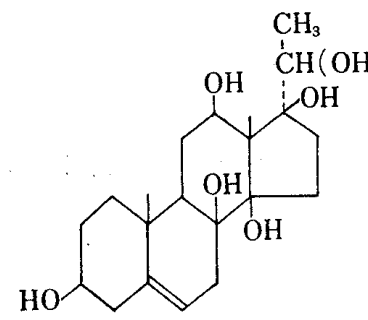

I<smiles>CC(C)(O)C1(O)CCC2(O)C3CCC4=CC(O)CCC4C3CC(O)C21O</smiles>

II $: \mathrm{R}=\mathrm{COCH}_{3}$ $\mathrm{IIa}: \mathrm{R}=\mathrm{H}$

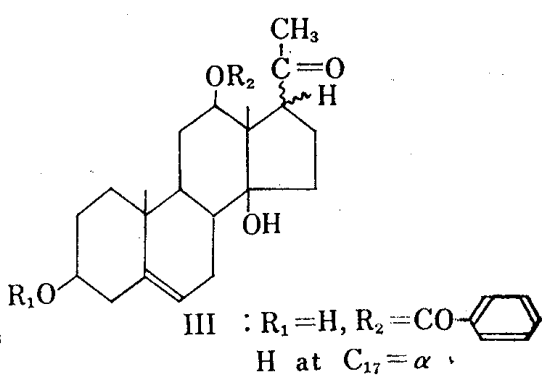

IIIa : $\mathrm{R}_{1}=\mathrm{R}_{2}=\mathrm{H}, \mathrm{H}$ at

$\mathrm{C}_{17}=\beta$

IIIb : $\mathrm{R}_{1}=\mathrm{R}_{2}=\mathrm{COCH}_{3}$

$\mathrm{H}$ at $\mathrm{C}_{17}=\beta$

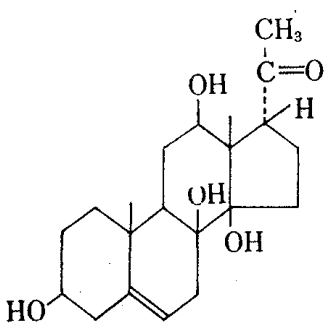

IV

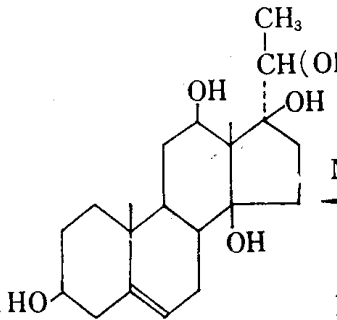

$\mathrm{V}$

$\mathrm{CH}_{3}$ $\stackrel{1}{\mathrm{C}}=0$

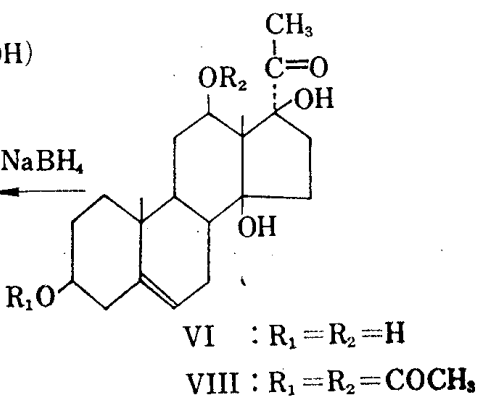

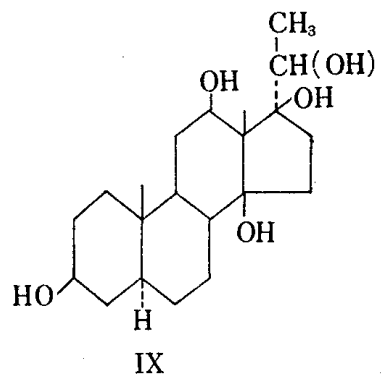

VIII : $\mathrm{R}_{1}=\mathrm{R}_{2}=\mathrm{COCH}_{3}$

Chart 1.

6) H. Mitsuhashi, T. Nomura, M. Fukuoka : Steroids, 4 : 4, 483 (1964).

7) C. Djerassi : "Optical Rotatory Dispersion Application to Organic Chemistry," McGraw-Hill Book Co., New York (1960).

8) H. Mitsuhashi, Y. Shimizu, E. Yamada, I. Takemori, T. Nomura: This Bulletin, 10, 808 (1962). 
17-H-20-one steroids to complete equilibrium mixture of the side chain in most cases. ${ }^{0,11)}$ The above facts strongly suggest that pergularin (V) has $\mathrm{C} / \mathrm{D}$ cis ring juncture, and $17 \beta-\mathrm{OH}, 17 \alpha-\mathrm{COCH}_{3}$ side chain. ${ }^{6)}$ Since sarcostin (I), and four other compounds (II, III, $\mathrm{N}, \mathrm{V}$ ), which have $3 \beta, 12 \beta, 14 \beta-\mathrm{OH}$ groups, have been isolated from the same plants, biogenetic analogy would favour the structure (V) for pergularin. This assumption was proved by the following results. Pergularin (V) was reduced with $\mathrm{NaBH}_{4}$, and the product examined by paper chromatography $\left(\mathrm{CHCl}_{3} /\right.$ formamide $),{ }^{8)}$ giving two spots. The major spot was identical with that of utendin $(\mathrm{V})$. On partition chromatography over Celite $\left(\mathrm{C}_{6} \mathrm{H}_{6}+\mathrm{BuOH} / \mathrm{H}_{2} \mathrm{O}\right)$, crystals, m.p. $240 \sim 250^{\circ}$, were isolated, which was identified with utendin $(\mathrm{V})$ by a mixed fusion. Utendin has been isolated from Pacycarpus lineolatus, ${ }^{10}$ ) $5 \alpha$-dihydroutendin $=$ tomentogenin $(\mathbb{X})$ from Marsdenia tomentos $a^{11}{ }^{11} \quad$ Recently, the structures of these compounds $(\mathrm{V}, \mathbb{X})$ were established by Reichstein's group ${ }^{12}$ and Mitsuhashi's group, ${ }^{13)}$ independently.

Thus perugularin is represented by the structure (V).

$\begin{array}{ll}\text { Faculty of Pharmaceutical Sciences, } & \text { Hiroshi Mitsuhashi (三橋 博) } \\ \text { School of Medicine, } & \text { Taro Nomura } \\ \text { Hokkaido University, } & \end{array}$

Received October 7, 1964

9) M. B. Rubin : Steroids, 2, 561 (1963).

10) E. Abish, Ch. Tamm, T. Reichstein : Helv. Chim. Acta, 42, 1014 (1959).

11) H. Mitsuhashi, I. Takemori, Y. Shimizu T. Nomura, E. Yamada : This Bulletin, 10, 804 (1962).

13) A. Lardon, W. Klyne, E. Iseli, T. Reichstein : IUPAC Symposium at Kyoto, Japan, On April 18, 1964.

13) H. Mitsuhashi, T. Sato, T. Nomura, I. Takemori : This Bulletin, 12, 981 (1964).

The Absolute Configuration of Optically Active Isovaline

Many of the recent studies on $\alpha$-alkyl- $\alpha$-amino acids have revealed that some of them have physiologically very interesting properties, ${ }^{1)}$ and few were found in natural products. ${ }^{2}$ The absolute configuration of these amino acids is either still unknown or just only suggestive. ${ }^{3 \sim 5)}$
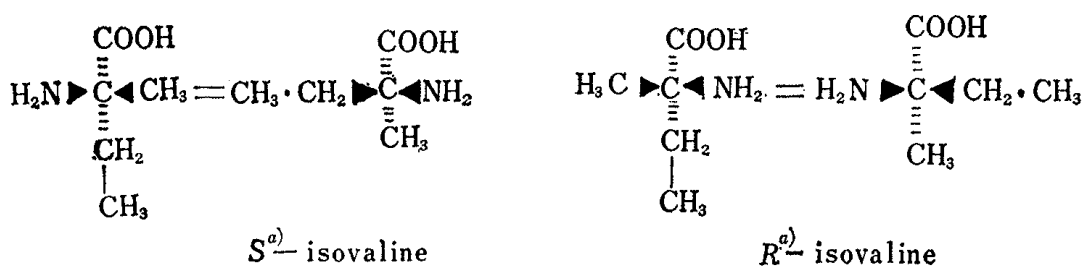

IIa $\quad \mathrm{Ilb}$

III a IIIb

a) cf. R.S. Cahn, C.K. Ingold, V. Prelog: Experientia, 12, 81 (1956).

1) a) L. Gillespie, Jr. : Ann. N. Y. Acad. Sci., 88, 1011 (1960). b) H. Smirk : Brit. Med. J., 1963, 146 and references therein. c) A. Sjoerdsma, S. Udenfriend : Biochem. Pharmacol., 8, 164 (1961).

2) a) E. H. Flynn, J. W. Hinman, E. L. Caron, D. O. Woolf, Jr. : J. Am. Chem. Soc., 75, 5867 (1953). b) Sheng-din Fang, Liang-chüan Li, Ching-i Niu, Kwong-fong Tseng: Sientia Sinica, 10, 845 (1961). c) Tsun-tsi Sun, Shuen-hsing Loh, Shu-wei Chow. Zu-yoong Kyi : Scientia Sinica, 10, 852 (1961). d) G. W. Kenner, R.C. Sheppard : Nature, 181, 48 (1958). e) M. Kandatsu, K. Kikuno : Agr. Biol. Chem. (Japan), 25, 234 (1961). 